\title{
Description of a new species of Wolfniana and new records of Rotigonalia (Hemiptera: Cicadellidae: Cicadellinae) from the state of Amazonas, Brazil
}

\author{
Rodney Ramiro Cavichioli \& Daniela Maeda Takiya²
}

\author{
${ }^{1}$ Departamento de Zoologia, Universidade Federal do Paraná. Caixa Postal 19020, 81531-980 Curitiba, PR, Brazil. \\ E-mail: cavich@ufpr.br \\ ${ }^{2}$ Laboratório de Entomologia, Departamento de Zoologia, Instituto de Biologia, Universidade Federal do Rio de Janeiro. \\ Caixa Postal 68044, 21941-971 Rio de Janeiro, RJ, Brazil. E-mail: takiya@gmail.com
}

\begin{abstract}
Wolfniana viridis sp. nov. is described and illustrated based on specimens collected in the municipality of Ipixuna (along Liberdade and Gregório rivers), state of Amazonas, Brazil. The new species can be distinguished from the type-species, W. limbatula (Osborn, 1926), by the color pattern which lacks conspicuous orange markings on head, pronotum, and forewing commissure; and aedeagal shaft with apex broadly expanded. Based on specimens of Rotigonalia concedula Melichar, 1926 and R. curvula Cavichioli, 2000, collected along with W. viridis, Rotigonalia Young, 1977 is firstly recorded from the state of Amazonas and $R$. concedula is firstly recorded from Brazil.
\end{abstract}

KEY WORDS. Auchenorrhyncha; Cicadellini; distribution; new record; new species.

Wolfniana was described by CAVICHIOLI (2001) to comprise solely Cicadella limbatula Osborn, 1926, which was previously included in Rotigonalia Young, 1977 along with the type-species, R. concedula (Melichar, 1926). CAvichioli (2001) diagnosed Wolfniana by the following combination of features: 1) head slightly produced anteriorly; 2) ocelli located before imaginary line between anterior eye angles; 3 ) epistomal suture incomplete; 4) pronotal width less than transocular width; 5) forewings with anteapical cells closed; 6) male pygofer without processes; 7) styles very short; and 8) paraphyses rami longer than aedeagus, symmetrical, and acute. Cavichioli's (2001) decision of removing Cicadella limbatula from Rotigonalia was based on the fact that this species does not present the male clypeus inflated at base, a diagnostic feature of the latter genus that is shared by the four species currently included in it (see Cavichioli 2000). Although all of the above-cited characteristics of Wolfniana individually are present in several Neotropical Cicadellini, the included species can be additionally distinguished from closely related genera in the Juliaca Melichar, 1926 generic group (Young 1977) by the following features: 1) mostly dark green colored pronotum and forewings; 2) short aedeagal shaft; and 3) paraphyses with broad transversal base, apical third of rami with pitted sculpturing.

Based on newly collected specimens from Ipixuna, state of Amazonas, Brazil, a new species of Wolfniana, W. viridis sp. nov., is described and illustrated. Additionally, specimens of Rotigonalia concedula Melichar, 1926 and R. curvula Cavichioli, 2000 were collected, representing the first record of Rotigonalia from the state of Amazonas and the first record of the former species from Brazil.

\section{MATERIAL AND METHODS}

The specimens studied herein are deposited in the following institutions: Instituto Nacional de Pesquisas da Amazônia, Manaus (INPA); Coleção Entomológica Prof. José Alfredo Pinheiro Dutra, Departamento de Zoologia, Universidade Federal do Rio de Janeiro, Rio de Janeiro (DZRJ); and Coleção Entomológica Pe. Jesus Santiago Moure, Departamento de Zoologia, Universidade Federal do Paraná, Curitiba (DZUP). The terminology follows mainly Young $(1968,1977)$, except for the head structures, which follows Hamilton (1981) and MejDalani (1998). Terminology for the leg chaetotaxy follows Rakitov (1997). Male terminalia were prepared according to OMAN (1949) with the following modifications: the terminalia were 1) soaked in boiling potassium hydroxide, 2) transferred to lactic acid in a water bath for five minutes, and then 3 ) transferred to 50\% ethanol in a water bath for two minutes to remove air bubbles. Terminalia were analyzed and photographed in glycerin and posteriorly stored in microvials. In quotations of label data, a reversed virgule ( $\backslash$ ) separates lines on the label.

\section{TAXONOMY}

\section{Wolfniana viridis Cavichioli \& Takiya, sp. nov. Figs 1-6}

Diagnosis. Small-sized sharpshooters; general coloration dark green; crown slightly produced, with anterior margin rounded; pronotum slightly narrower than transocular width, lateral margins slightly convergent anteriorly; aedeagus shaft short and slightly curved ventrally. 

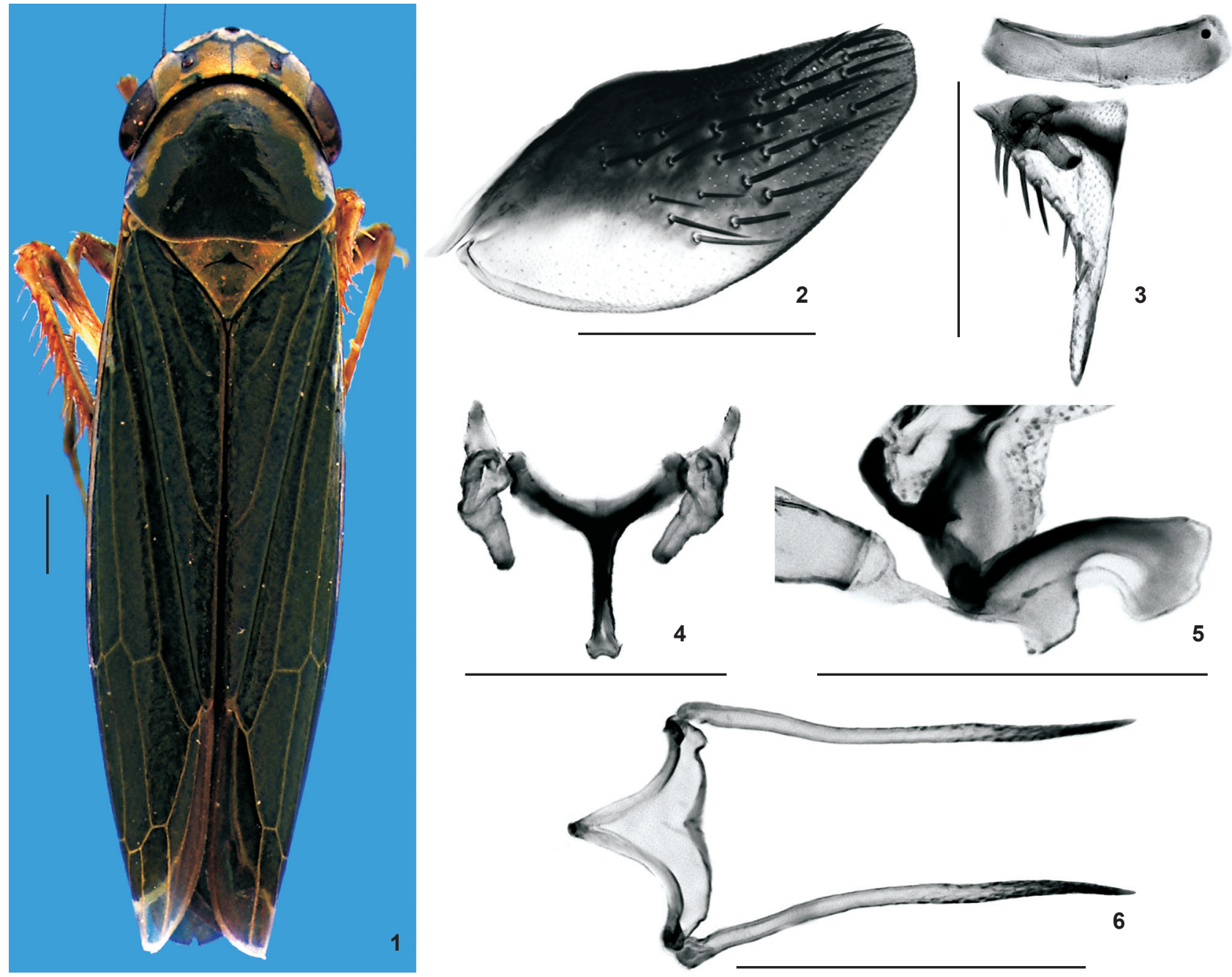

Figures 1-6. Wolfniana viridis sp. nov., male holotype: (1) dorsal habitus; (2) pygofer, lateral view; (3) valve and right subgenital plate, ventral view; (4) styles and connective, dorsal view; (5) aedeagus, lateral view; (6) paraphyses, dorsal view. Scale bars $=1.0 \mathrm{~mm}$.

Description (male). Length 5.94 (holotype) - $6.12 \mathrm{~mm}$. Head and thorax. Crown (Fig. 1) slightly produced, anterior margin rounded; median length of crown almost four-fifths of interocular width and one-fourth of transocular width; coronal suture extending anteriorly almost to anterior margin. Pronotum slightly narrower than transocular width, lateral margins slightly convergent anteriorly; posterior margin almost straight. Forewings with distal membrane covering apical half of apical cells. Hindtibiae with anterodorsal row of macrosetae with short intercalary setae (approximately two in between each pair of macrosetae). Other characteristics as in the generic description (CAVICHIOLI 2001).

Coloration. Head (Fig. 1) greenish-yellow; median spot on anterior margin, zig-zag transverse line over epicranial, frontogenal, and temporal (anterior to ocelli) sutures, black; frons and clypeus black. Pronotum (Fig. 1) dark-green with anterior margin greenish-yellow; prosternum black; pleurae and legs castaneous. Mesonotum (Fig. 1) greenish-yellow; black transverse line over scutoscutellar suture. Forewings (Fig. 1) dark green with translucent membrane.

Male genitalia. Pygofer (Fig. 2) elongate, apex truncate; without process; macrosetae distributed from basal third to apex. Valve (Fig. 3) almost linear; anterior margin broadly concave; posterior margin broadly convex. Subgenital plates (Fig. $3)$, in ventral view, subtriangular, strongly narrowed on apical third; uniseriate macrosetae from base to apical third; apex acute. Styles (Fig. 4) very short; shorter than connective; apex truncate. Connective (Fig. 4) Y-shaped; arms widely divergent, almost as long as median stalk. Aedeagus (Fig. 5) shaft short; curved ventrally, ventral margin with a medially strong groove; 
base and apex broad. Paraphyses (Fig. 6) with broad T-shaped base articulated with rami; rami long and narrow, apical third with pitted sculpturing, apex acute.

Female unknown.

Type material. Brazil, state of Amazonas. Holotype: male, "Ipixuna-Am; Rio $\backslash$ Gregório; Com. [Comunidade] Lago $\backslash$ Grande. Seringal $\backslash 7^{\circ} 10^{\prime} 6^{\prime \prime} \mathrm{S} 70^{\circ} 49^{\prime} 6^{\prime} \mathrm{W}$ ", " $145 \mathrm{~m}$ - light trap $\backslash 18-23 / \mathrm{V} /$ $2011 \backslash$ Cavichioli, Gonçalves \& \Takiya" (INPA). Paratype: one male, "Ipixuna - Am; Rio \Liberdade; Com. [Comunidade] São \Vicente (Estirão da \Preta) $7^{\circ} 21^{\prime} 47^{\prime \prime} \backslash 71^{\circ} 52^{\prime} 7^{\prime \prime} W^{\prime \prime}, ~ " 175 m$ - Malaise $\backslash 11$ 14/V/2011 \Cavichioli, Gonçalves \& \Takiya” (DZUP).

Etymology. The new species epithet refers to the completely dark green general color, which distinguishes it from the only other known Wolfniana species.

Remarks. Wolfniana viridis sp. nov. is assigned to Wolfniana based on features discussed in the introduction. The new species is very similar to $W$. limbatula, but it can be readily distinguished from it by: 1) color pattern lacking orange markings on head, pronotum, and forewing commissure; and 2) aedeagus shaft with apex broadly expanded.

The new species was collected in the municipality of Ipixuna, state of Amazonas, in a terra-firme forest along Gregório and Liberdade rivers, somewhat close to the borders of the state of Acre and Peru. Specimens were collected with mixed mercury light and Malaise traps. Wolfniana is known only from the Amazon basin, considering that specimens of $W$. limbatula were studied from Brazil (Amazonas, Mato Grosso, and Rondônia states) and Ecuador (CAVICHIOLI 2001), and recorded by Young (1977) from French Guiana. Records of this species from Southern Brazil (Young 1977, CAvichioli 2001) are erroneous. They were based on localities listed by OsBorn (1926) that are actually in the state of Rondônia (Santo Antônio de Guaporé and Rio Guaporé near Porto Príncipe, along Guaporé river, on the border with Bolivia). Young (1977) lists this species as occurring in Costa Rica. However, photographed specimens from Costa Rica deposited at the North Carolina State University (Wilson et al. 2009) have a very different color pattern and might represent a different species or genus.

\section{Rotigonalia concedula (Melichar, 1926)}

Material studied. Four males and three females from Brazil, state of Amazonas. One male and one female, "Ipixuna - Am; Rio \Liberdade; Com. [Comunidade] São $\backslash$ Vicente (Estirão da $\backslash$ Preta) $7^{\circ} 21^{\prime} 47^{\prime \prime} \backslash 71^{\circ} 52^{\prime} 7^{\prime \prime} W^{\prime}$, " $175 \mathrm{~m}$ - Sweep $\backslash 11-14 / \mathrm{V} / 2011 \backslash$ Cavichioli, Gonçalves \& \Takiya" (INPA); one male and one female, same data as preceding (DZRJ); one male, same data as preceding, except "Malaise" instead of "Sweep" (INPA); one male and one female, "Ipixuna - Am; Rio \Gregório; Com. [Comunidade] Lago \Grande. Seringal $\backslash 7^{\circ} 10^{\prime} 6^{\prime} \mathrm{S} 70^{\circ} 49^{\prime} 6^{\prime} \mathrm{W}^{\prime}$, " $145 \mathrm{~m}$ - sweep $\backslash 18-23 / \mathrm{V} /$ 2011 \Cavichioli, Gonçalves \& \Takiya" (DZUP).

Remarks. This species was previously known from Bolivia and Peru (Young 1977) and was the only Rotigonalia not recorded from Brazil.

\section{Rotigonalia curvula Cavichioli, 2000}

Material studied. One male from Brazil, state of Amazonas. One male, "Ipixuna - AM, Rio \Liberdade, Com. [Comunidade] São $\backslash$ Vicente (Estirão da $\backslash$ Preta) $7^{\circ} 21^{\prime} 47^{\prime}$ "S $\backslash 71^{\circ} 52^{\prime} 7^{\prime \prime} W^{\prime}$, " $175 \mathrm{~m}$ Malaise $\backslash 11-14 / \mathrm{V} / 2011 \backslash$ Cavichioli, Gonçalves \& $\backslash$ Takiya” (INPA). Remarks. This species was described from the state of Pará, Brazil, and is herein firstly recorded from Amazonas State.

\section{ACKNOWLEDGMENTS}

A preliminary version of this manuscript benefited from comments and corrections by Gabriel Mejdalani (Museu Nacional, Universidade Federal do Rio de Janeiro) and two anonymous reviewers. The senior author is a research productivity fellow from Conselho Nacional de Desenvolvimento Científico e Tecnológico (CNPq; process 303.127/2010-4). This research was partially funded by PROTAX/CNPq research grants to the senior (process 561.298/2010-6) and junior (process $562.303 / 2010-3)$ authors. This paper is contribution number 1866 of the Departamento de Zoologia, Universidade Federal do Paraná. Collection of the specimens was possible thanks to the project "Amazonas: Diversidade de insetos ao longo de suas fronteiras", headed by José A. Rafael (INPA, PRONEX, FAPEAM, process 1437/2007/NTO318/07).

\section{LITERATURE CITED}

CAVICHIOLI, R.R. 2000. Descrição de três novas espécies de Rotigonalia Young (Hemiptera: Auchenorrhyncha: Cicadellidae) com chave para as espécies. Anais da Sociedade Entomológica do Brasil 29: 683-689.

Cavichioli, R.R. 2000 [2001]. Wolfniana gen. n. and redescription of Wolfniana limbatula (Osborn, 1926) comb. nov. (Hemiptera, Auchenorrhyncha, Cicadellidae). Insecta Mundi 14: 253-255.

Hamilton, K.G.A. 1981. Morphology and evolution of the rhynchotan head (Insecta: Hemiptera, Homoptera). Canadian Entomologist 113: 953-974.

Mejdalani, G. 1998. Morfologia externa dos Cicadellinae (Homoptera, Cicadellidae): comparação entre Versigonalia ruficauda (Walker) (Cicadellini) e Tretogonia cribrata Melichar (Proconiini), com notas sobre outras espécies e análise da terminologia. Revista Brasileira de Zoologia 15: 451-544.

Oman, P.W. 1949. The Nearctic leafhoppers (Homoptera: Cicadellidae). A generic classification and check list. Memoirs of the Entomological Society of Washington 3: 1-253.

Osborn, H. 1926. Neotropical Homoptera of the Carnegie Museum. Part 5. Report upon the collections in the subfamily Cicadellinae, with descriptions of new species. Annals of the Carnegie Museum 16: 155-248.

RaKitov, R.A. 1997. On differentiation of the cicadellid leg chaetotaxy (Homoptera: Auchenorrhyncha: Membracoidea). Russian Entomological Journal 6: 7-27. 
Wilson, M.R.; J.A. Turner; \& S.H. McKamey. 2009. Sharpshooter Leafhoppers of the World (Hemiptera: Cicadellidae subfamily Cicadellinae). National Museum Wales. Available online at: http://naturalhistory.museumwales.ac.uk/ Sharpshooters. [Accessed: 17/I/2012]

Young, D.A. 1968. Taxonomic study of the Cicadellinae

Submitted: 08.XI.2011; Accepted: 17.I.2012.

Editorial responsibility: Gabriel L.F. Mejdalani
(Homoptera: Cicadellidae), Part 1, Proconiini. Bulletin of the United States National Museum 261: 1-287.

Young, D.A. 1977. Taxonomic study of the Cicadellinae (Homoptera: Cicadellidae), Part 2, New World Cicadellini and the genus Cicadella. Technical Bulletin of the North Carolina Agricultural Experiment Station 239: 1-1135. 